\title{
Carcass Characteristics of Purebred Tsurcana Lambs and F1 Crossbreds (Tsurcana $X$ Vendeen)
}

\author{
Ioan PAȘCA ${ }^{1}$, Adrian CÎMPEAN ${ }^{1}$, Dana PUSTA ${ }^{1}$, Liviu BOGDAN ${ }^{2}$, Emoke PALL ${ }^{2}$, Alexandra TĂBĂRAN ${ }^{1}$, \\ Cristina Laura BOTA ${ }^{3}$, Mihai Marian BORZAN ${ }^{1 *}$
}

${ }^{1}$ Department of Animal Productions and Food Safety, USAMV Cluj, Romania

${ }^{2}$ Department of Clinics, USAMV Cluj, Romania

${ }^{3}$ S.C.Agrocons Parox SRL

*corresponding author: mihai_borzan@yahoo.com

Bulletin UASVM Veterinary Medicine 75(1)/2018

Print ISSN 1843-5270; Electronic ISSN 1843-5378

doi:10.15835/buasvmcn-vm:005717

\begin{abstract}
The data presented in this article is included in a larger research regarding the improvement of the Romanian lamb towards the meat production. The study has been carried out from 2015 to 2016. The lambs included in this study were obtained following a protocol of estrus synchronization in Tsurcana ewes and the grouped lambing. The research is a pilot study conducted on a representative sample for the selected groups of animals and further research is needed to complete the research. The research aims to compare carcass characteristics of purebred Tsurcana lambs and Tsurcana crossed with Vendeen lambs. The criteria assessed were: the chemical composition of purebred and crossbred meat, the live body weight, the slaughtering performance and the weight of different carcass cuts. For almost all criteria chosen the crossbred individuals recorded better results.
\end{abstract}

Keywords: lamb carcass, meat quality, Tsurcana, Vendeen

\section{Introduction}

The human migration from the Middle East toward the northern and eastern European countries, as well as the option of the western buyer, makes a transition in the human's nutritional habits, which is also orientated towards the consumption sheep's meat. The market is adapting to the new demands by importing the meat from the southern hemisphere (Australia, New Zealand, etc), but the freshness and price of the meat is affected. A good option is to improve the meat production in the sheep sector in order to cover the market demands, but this practice is limited by the need of balance between the animal productions and the limited available space for the agriculture. This new challenge needs to be managed carefully. For Romania, the important number of sheep represents a good opportunity for the country to support the internal EU production of meet. In theory, by producing crossbreds with the local breeds (like Tsurcana), the meat production will be improved. Nowadays, the meat quality and quantity is thoroughly checked and often, the price is paid accordingly. The scientific research to check the improved quality in the crossbred's carcasses is important and can serve as a guide for the communities to obtain a product suitable for the EU market.

The Tsurcana sheep breed is an old and rustic type breed, resistant, very well adapted to the Romanian pedo-climatic conditions (from plains to mountains), being the most numerous breed in Romania. Also it has good meat production characteristics and it is suitable for crossing with other sheep breeds specialized for meat production, to obtain F1 crossbreds according to market demands (Georgescu et al., 2000; FAO 2014). The quality of the sheep meat is influenced by many factors including genetic and environmental factors (Pascal et al., 2014).

The Vendeen breed was developed by crossing local french ewes with Southdown rams in the 
early 19th century. It is considered primarily a meat breed known for its muscularity and ability to produce large litters of lambs.

The crossing of Tsurcana ewes with a French meat breed like Vendeen is important to increase the quality of the resulting lamb's carcasses. In literature, there were no publications regarding the crossing of these two breeds, this research being the first that compares the improvements of the crossbred lambs with the purebred Tsurcana.

This is an original research and presents preliminary data regarding the carcass characteristics of the crossbred lambs resulted from the crossing of the French sheep breed (Vendeen) with the purebred Tsurcana.

The aim of this research was to compare some quality characteristics of purebred Tsurcana lamb's meat with Tsurcana crossed with Vendeen lamb's meat.

Hypothesis $\mathbf{H} \mathbf{1}_{\mathbf{0}}=$ The carcass quality of purebred Tsurcana lambs $\left(\mu_{1}\right)$ and Tsurcana $X$ Vendeen lambs $\left(\mu_{2}\right)$ is identical: $\mu_{1}=\mu_{2}$

Hypothesis $\mathbf{H} \mathbf{1}_{\mathbf{1}}=$ The carcass quality of purebred Tsurcana $\left(\mu_{1}\right)$ and Tsurcana X Vendeen lambs $\left(\mu_{2}\right)$ is different: $\mu_{1} \neq \mu_{2}$

Hypothesis $\mathbf{H} \mathbf{2}_{\mathbf{0}}=$ Carcass quality of Tsurcana $X$ Vendeen lambs $\left(\mu_{2}\right)$ is identical of those purebred Tsurcana $\left(\mu_{1}\right)$, regardless of the body cut analyzed (full leg, shoulder, Longisimus dorsi, ribs): $\mu_{1}=\mu_{2}$

Hypothesis $\mathbf{H 2} \mathbf{1}_{\mathbf{1}}$ Carcass quality of Tsurcana $X$ Vendeen lambs $\left(\mu_{2}\right)$ is different of those purebred Tsurcana $\left(\mu_{1}\right)$, regardless of the body cut analyzed (full leg, shoulder, Longissimus dorsi, ribs): $\mu_{1} \neq \mu_{2}$

\section{Materials and methods}

The data presented in this article is included in a larger research regarding the improvement of the Romanian lamb towards the meat production. The study has been carried out from 2015 to 2016 .

The lambs included in this study were obtained following a protocol of estrus synchronization in Tsurcana ewes and the grouped lambing. 50 Tsurcana ewes were mated with Tsurcana rams, resulting purebred Tsurcana lambs and 50 Tsurcana ewes were mated with Vendeen rams, resulting the F1 crossbred lambs. After lambing, out of the crossings we obtained 48 crossbred and 48 purebred lambs. All the lambs were kept in similar housing conditions and supplied with the same feedings, according to their age.
The body weight evolution was periodically evaluated at birth, 21, 50, 90 and 120 days. The average of live bodyweight at 120 days was $25.04 \pm 0.99 \mathrm{~kg}$ for purebred Tsurcana lambs and $30.22 \pm 1.5 \mathrm{~kg}$ for crossbreds. The representative sample of animals to be slaughtered was assessed with Tarro-Yamane formula (GfK, 2013, Poland):

$$
n=\frac{N}{1+N *(e)^{2}}
$$

95\% confidence level and $\mathrm{p}=0.5$ are assumed $\mathrm{n}=$ the sample size

$\mathrm{N}=$ the population size

$\mathrm{e}=$ the acceptable sampling error

The calculated number of selected lambs to be slaughtered was 3.69 for both groups; five male lambs were selected from each group and were sacrificed. The10 lambs were randomly chosen. The slaughtering was performed in an authorized place accordingly to the EU legislation.

After slaughtering, for each lamb the carcass weight was assessed and the best cuts of the carcass were weighted and recorded. Then, the bones to muscles and muscles to fat ratios were assessed according to protocols found in literature (Fahmy et al., 1992; Geay et al.. 2002; Laville et al., 2002). Samples were collected from the carcass in order to be analyzed with a Food scanner which can accurately detect the protein content, the water, the fat, and the collagen percentage of the carcass. The chemical analysis was performed with the FoodScan ${ }^{\mathrm{TM}}$ for meat.

The quality parameters assessed in this study were as follows: the chemical composition of purebred and crossbred Tsurcana lamb meat; the live body weight and the slaughtering performance; weight of different carcass cuts (full leg, shoulder, Longissimus dorsi, ribs).

The results were statistically analyzed by comparing the obtained averages between the control group end each test group using Microsoft Excel, ANOVA test and t-Test, mean values and standard deviation, at $\mathrm{p}=0.05$.

\section{Results and discussion}

The Tsurcana breed is a local, rustic and resistant breed, well adapted to the Romanian pedo-climatic conditions. It is one of the most 
Table 1. Mean values and standard deviation for certain chemical componds of meat from purebred Tsurcana and Tsurcana X Vendeen crossbred lambs

\begin{tabular}{ccccc}
\hline & Water \% & Fat \% & Protein \% & Collagen \% \\
\hline Tsurcana purebred & $75,03 \pm 1,69$ & $4,9 \pm 1,10$ & $17,26 \pm 0,35$ & $1,87 \pm 0,16$ \\
\hline Tsurcana+Vendeen & $72,34 \pm 1,41$ & $7,68 \pm 1,01$ & $17,57 \pm 0,20$ & $1,83 \pm 0,20$ \\
\hline
\end{tabular}

Table 2. Statistical analysis of body weight at slaughtering in purebred Tsurcana and Tsurcana X Vendeen crossbred lambs

\begin{tabular}{|l|c|c|c|c|c|c|}
\hline & Ts urcana purebred & Ts urcana X Vendeen & \multicolumn{2}{|l|}{ Test ANOVA } & \multicolumn{2}{|c|}{ tTest } \\
\cline { 2 - 7 } & $\begin{array}{c}\text { Mean values and } \\
\text { standard deviation }\end{array}$ & $\begin{array}{c}\text { Mean values and } \\
\text { standard deviation }\end{array}$ & F & F crit & t Stat & $\begin{array}{c}\text { t Critical } \\
\text { two-tail }\end{array}$ \\
\hline Liveweight $(\mathrm{kg})$ & $28,82 \pm 1,70$ & $37,46 \pm 6,63$ & 23,19 & 5,31 & $-4,81$ & 2,30 \\
\hline Carcass weight $(\mathrm{kg})$ & $13,40 \pm 0,71$ & $19,3 \pm 1,81$ & 45,92 & 5,31 & $-6,77$ & 2,30 \\
\hline Full leg weight $(\mathrm{kg})$ & $3,96 \pm 0,26$ & $6,4 \pm 0,79$ & 42,64 & 5,31 & $-6,53$ & 2,30 \\
\hline Shoulder weight(kg) & $2,78 \pm 0,19$ & $3,92 \pm 0,59$ & 16,70 & 5,31 & $-4,08$ & 2,30 \\
\hline Longisimum dorsi weight $(\mathrm{kg})$ & $0,32 \pm 0,04$ & $0,52 \pm 0,08$ & 22,22 & 5,31 & $-4,71$ & 2,30 \\
\hline Ribs weight $(\mathrm{kg})$ & $4,72 \pm 0,08$ & $6,64 \pm 0,85$ & 25,24 & 5,31 & $-5,02$ & 2,30 \\
\hline Slaughtering performance $(\%)$ & $46,51 \pm 0,64$ & $51,54 \pm 1,15$ & 72,87 & 5,31 & $-8,53$ & 2,30 \\
\hline
\end{tabular}

representative Romanian breeds, but it has a medium productivity for meat production. To improve the meat production, the crossing with French meat breeds is to be considered. In this research we aimed to realize a technological model to improve the meat production in sheep sector. Even though the Tsurcana breed it was used before in crossings with other meat breeds and proved to be successful in crossings, in literature there were no other studies concerning a crossing with Vendeen breed.

Comparing the results of the chemical analysis of the carcasses of purebred Tsurcana lambs and crossbred Tsurcana X Vendeen lambs revealed that the water had higher values in the meat of purebred Tsurcana lambs $(75.03 \pm 1.69$ compared with $72.34 \pm 1.41$ ), and the fat quantity was high in the carcass of crossbred lambs $(7.68 \pm 1.01$ compared with $4.90 \pm 1.10$ ).

The percent of the protein and collagen were almost equal for both the carcasses of purebred and crossbred lambs, slightly higher values for protein were recorded in crossbreds and slightly higher collagen values were recorded in purebreds (table 1).
Mean values and standard deviation of body weight in Tsurcana X Vendeen crossbreds and in Tsurcana purebred are shown in Table 2. It can be observed that the average slaughtering performance is superior in crossbreds than in the purebred lambs and all the averages of all the analyzed cuts, even though they had the same age and were kept in the same conditions.

The results are similar to other researches concerning the purebred Tsurcana (Pascal C., Nechifor I.), but there are no studies for the crossings of the Vendeen breed with Tsurcana.

Average and standard deviation for live body weight, carcass weight, full leg weight, shoulder weight, longissimus dorsi weight, ribs weight and slaughtering performance for the slaughtered lambs revealed differences for the crossbred lambs. They recorded higher values compared to purebreds (Table 2).

Statistical analysis using ANOVA single factor test and T-test confirms that there is a statistical difference between the live weight of the purebred Tsurcana lambs compared with crossbreds, at $\mathrm{p}=0.05(\mu 1 \neq \mu 2)$. The average of the life body weight in crossbreds is superior to that of the 
Table 3. Meat/bone ratio and meat/fat ratio at crossbreds Tsurcana X Vendeen and purebred Tsurcana lambs

\begin{tabular}{ccc}
\hline & Bone/meat ratio & Meat/fat ratio \\
\hline Tsurcană X Vendeen & $1: 3.93$ & $7,83: 1$ \\
\hline Tsurcană X Tsurcană & $1: 3.75$ & $14,57: 1$ \\
\hline
\end{tabular}

Table 4. The carcass share of the primary cuts with high commercial value $(\%)$

\begin{tabular}{ccc}
\hline Cuts & Tsurcana x Vendeen & Purebred Tsurcana \\
\hline Full leg & 56,02 & 53,78 \\
\hline Cutlet & 24,33 & 23,49 \\
\hline Neck and shoulder blade & 19,65 & 22,73 \\
\hline Breast and chump & 56,02 & 53,78 \\
\hline
\end{tabular}

purebreds at the same age and kept in the same conditions $(23,19>5,31)$. (Table 2)

Statistical analysis using ANOVA single factor test and T-test revealed that there is statistical difference at $\mathrm{p}=0.05$ between the slaughtering performance of the crossbred Tsurcana lambs and purebreds $(\mu 1 \neq \mu 2)(72,87>5,31)$. (Table 2$)$

In the literature, there were no other similar studies to compare the results of our study. The research is original and represents the first crossing between Vendeen rams and Tsurcana ewes.

Concerning the carcass weight $(45,92>5,31)$, the full leg weight $(42,64>5,31)$, the shoulder weight $(16,70>5,31)$, Longissimus dorsi weight $(22,22>5,31)$ and the ribs weight $(25,24>5,31)$ resulted after the butchering of the lambs, the results of ANOVA test revealed that: $\mathrm{F}>\mathrm{F}$ crit, the results cancel the $\mathrm{H} 2$ hypothesis and accepts the $\mathrm{H} 2{ }_{1}$ hypothesis, according to which the weights of the cuts are different between purebreds and crossbreds Tsurcana lambs.

The carcass weight, the full leg weight, the shoulder weight, Longissimus dorsi weight and the ribs weight resulted after the butchering of the lambs were statistical analyzed using the t-Test method: t Stat < - t Critical two-tail, respectively $-6.77<-2.30 ;-6.53<-2.30 ;-4.08<-2.30 ;-4.71<$ $-2.30 ;-5.02<-2.30$. The results suggest that $\mathrm{H}_{2}$ hypothesis is rejected and the $\mathrm{H} 2$ hypothesis is accepted meaning that carcass, full leg, shoulder, Longissimus dorsi and ribs weights resulted from the crossed Tsurcana with Vendeen lambs are different that the weights of purebred Tsurcana lambs, the crossbreds recording superior weights, fact confirmed by the statistical difference at $p=0.05$.

The bones/meat ratio reveals similar values, with a slight difference for the crossbreds. Superior values were recorded for the crossbred Tsurcana with Vendeen lambs carcass analysis compared with purebred Tsurcana

The meat/fat ratio in crossbreds was superior for crossbreds compared with the ratio recorded for purebreds Tsurcana lambs. (Table 3)

The full leg and the cutlet are the primary cuts with high commercial value and with higher meat share in the carcass representing superior quality (Fahmy et al., 1992; Pascal et al., 2014). The crossbreds Tsurcana lambs recorded a higher percent in the carcass comparative to the purebred Tsurcana lambs for the primary cuts (Table 4).

The study confirmed the hypothesis which stated that there are significant differences at $\mathrm{p}=0.05$ between the analyzed data of crossbreds Tsurcana with Vendeen lambs and purebreds lambs, except for the slaughtering performance.

The data obtained in our study, on the representative, crossbred and purebred lambs, samples can be extrapolated only for the batches of our study. The results revealed important contribution to improve the meat production in sheep sector and need further research, by using the described method in larger batches and with different genetics in order to generalize to the entire genotype group of sheep.

\section{Conclusions}

The research confirmed the advantages of crossing the local Tsurcana breed with Vendeen 
breed; the resulted crossbred lambs presented superior development compared with purebred Tsurcana lambs.

The study recorded the preliminary results of a research concerning a technology to improve the meat quality in sheep sector.

The quality of meat parameters evaluated (bone-meat ratio, meat-fat ratio, chemical content of the carcass) was associated with the fattening status of the carcasses and were superior for the crossbred lambs compared with the purebred Tsurcana lambs, even if the lambs were kept in similar conditions.

The analysis performed on crossbreds (live bodyweight and carcass) confirmed that the crossing of the Tsurcana ewes with Vendeen rams improves the quality characteristics of the Romanian lambs, demanded in the EU market.

Acknowledgements: This work has benefited from financial support through the PN-II-PTPCCA-2013-4-1239 project, No: 152/01.07.2014, "Obtaining the Romanian meat lamb - OVICARO".

\section{References}

1. Analysis of sample size in consumer surveys, GfK, Poland (2013). https://www.scribd.com/document/365896163/pl-gfk-k-pusczak-sample-size-incustomer-surveys-v2-2-pdf

2. Fahmy MH, Boucher MJ (1992). Feed efficiency, carcass characteristics and sensory quality of lambs. Journ of Anim Sci, 70: 1365-1374.
3. FAO STATISTICAL YEARBOOK (2014). Europe and Central Asia Food and Agriculture, Food and Agriculture Organization of the United Nations Regional Office for Europe and Central Asia Budapest, E-ISBN 978-92-5108168-6.

4. Geay Y, Bauchart D, Hocquette JF, Culioli J (2002). Valeur dietetique et qualites sensorielles des viands de ruminantes. Incidence de l'alimentation des animaux. INRA Prod Anim, 15: 37-52.

5. Georgescu B, Banu C, Croitoru C, Savu C, Tafta V, Van I, Lungu S, Movileanu G (2000). Tratat de producerea, procesarea si valorificarea carnii. Bucuresti: Ceres.

6. Laville E, Bouix J, Sayd T, Eychenne F, Marcq F, Leroy PL, Elsen JM, Bibe B (2002). La conformation bouchere des agneaux. Etude d'apres la variabilite genetique entre races. INRA, Productions animales, 15 : 53-66.

7. Mihaiu M, Tăbăran A, Mihaiu R, Dan SD, Reget $\mathrm{O}$, Cordiș I, Cordea D, Mureşan C (2015). Compositional Studies on Some Additive Concentrations Found in Meat Products Marketed in a Regional Area. Bulletin UASVM Veterinary Medicine, 72: 53-56.

8. Pascal C, Nechifor I (2014). The effect of crossing romanian sheep breeds with rams of meat breeds over the specific indicators of meat production, Lucrări Ştiinţifice - Seria Zootehnie, Iasi, 61: 25-31.

9. Pascal C, Ivancia M, Gilca I., Nacu Gh, Iftimie N (2009). Carcass quality of F1 crossings of Ile de France rams with local Romanian sheep, EAAP 2009, 60th Annual Meeting, Barcelona, Spain, Section S 49 b. Sheep and goat feeding and breeding free communications, 1-8.

10. Schmid A, Collomb M, Sieber R, Bee G (2006). Conjugated linoleic acid in meat and meat products. A review. Meat Sci, 73: 29-41. 